\title{
The Polar Front position during glacial abrupt climate change events and its impact on the hydrography and productivity along the western Iberian margin
}

\author{
Antje Voelker and Emilia Salgueiro (UGM-LNEG \& CIMAR LA, Portugal) \\ The western Iberian margin has been one of the key locations to study abrupt glacial climate \\ change and associated interhemispheric linkages. The regional variability in the response to such \\ events during the last glacial is being reconstructed using a suite of cores between 43 and $36^{\circ} \mathrm{N}$. \\ Based on evidence from hydrography-related proxy records (\% N. pachyderma (s); sea surface \\ temperatures (SST)), the polar front reached the northern Iberian margin (ca. $41^{\circ} \mathrm{N}$ ) during all \\ Heinrich stadials (HS) of the last glacial cycle, while the arctic front and the atmospheric Polar \\ Front were located in the vicinity of $39^{\circ} \mathrm{N}$. During HS, SST increased southward by about $1{ }^{\circ} \mathrm{C}$ \\ per one degree of latitude leading to steep temperature gradients in the eastern North Atlantic and \\ pointing to a close vicinity between subpolar and subtropical waters. Within the age constraints \\ of the respective records, surface water cooling during HS and sometimes also Greenland stadials \\ (GS) lasted longer, mainly because cooling started earlier in the north, in agreement with the \\ Polar Front reaching this region first. The southern Iberian margin was always bathed by \\ subtropical water masses (surface and/ or subsurface) and SST evolution was in general similar in \\ the Sines region $\left(38^{\circ} \mathrm{N}\right)$ and the central Gulf of Cadiz $\left(36^{\circ} \mathrm{N}\right)$, including no cooling during GS 11 . \\ The boundary at $39^{\circ} \mathrm{N}$ also impacted productivity with productivity being strongly reduced \\ during HS and GS north of it. South of the boundary the response varied with no clear pattern for \\ HS or GS. Off Sines productivity during HS 5 and 4 was increased, while reduced during parts of \\ HS 3, HS 2 and 1. In the Gulf of Cadiz, on the other hand, productivity always increased during \\ HS and most GS. Based on our observations sufficient paleo-data now exists to validate regional \\ climate models for abrupt climate change events in the northeastern North Atlantic Ocean.
}

Poster at XVIII INQUA-Congress: Quaternary sciences - the view from the mountains. 21-27 July 2011 in Bern, Switzerland 